\title{
Design Improvement of Pindad Mini Excavator Boom Using Finite Element Method
}

\author{
Azhari Sastranegara',a, Zairullah Azhar²,b \\ 1,2Mechanical Engineering Study Program, Faculty of Engineering, President University \\ JI. Ki Hajar Dewantara, Jababeka Education Park, Bekasi 17550 \\ aazhari.sastranegara@president.ac.id, bzairullah.azharr@gmail.com
}

\begin{abstract}
Abstrak.
Makalah ini menyajikan analisis mini excavator excava 50 dengan fokus pada komponen boom. Komponen boom adalah komponen yang memiliki beban kerja berat. Bahan yang digunakan dalam desain yang ada adalah SM490A. Hasil analisis masih tidak aman karena stres yang diijinkan kurang dari stres kerja. Bahan dalam desain yang ada diganti dengan Hardox 400. Desainnya dinyatakan aman. Namun, biaya produk telah meningkat karena bahan Hardox 400 lebih mahal daripada SM490A. Untuk mengurangi biaya produk, diperlukan perbaikan desain untuk mengoptimalkan penggunaan material. Metode perbaikan desain yang digunakan dalam penelitian ini sesuai dengan metode optimasi, yaitu ukuran dan optimasi bentuk. Setelah perbaikan desain, untuk memprediksi berapa lama komponen boom dapat digunakan, prediksi umur kelelahan dihitung menggunakan teori Goodman.
\end{abstract}

Kata kunci. Boom, Excavator Mini, Metode Elemen Hingga, Peningkatan Desain, Masa Kelelahan

\begin{abstract}
.
This paper presents the analysis of mini excavator excava 50 with a focus on the boom component. The boom component is a component that has a heavy workload. The material used in the existing design is SM490A. The results of the analysis are still not safe because allowable stress is less than working stress. The material in the existing design was replaced with Hardox 400. The design is declared safe. However, the costs of the product have increased because Hardox 400 materials are more expensive than SM490A. To reduce the costs of the product, design improvement is needed to optimize the use of material. The design improvement method that uses in this study is according the optimization method, that is sizing and shape optimization. After improvement the design, to predict how long the boom component can be used, fatigue life prediction is calculated using Goodman's theory.
\end{abstract}

Keywords. Boom, Mini Excavator, Finite Element Method, Design Improvement, Fatigue Life

\section{Introduction}

The development of infrastructure in Indonesia recently is growing rapidly, especially road infrastructure to connect rural areas with urban areas. But in reality, road infrastructure development still has a few obstacles, especially in rural areas. Difficult mobility is the main obstacle factor, especially for heavy equipment. The need for small heavy equipment in order to reach remote areas [1].

To support the acceleration of road infrastructure development in rural areas, one of Indonesia's stateowned enterprises. That is PT. Pindad (Persero) has innovation in making to make small-scale excavators called Excava 50. Excava 50 is classified as Mini Excavator, which is a type of heavy equipment whose function is to complete a variety of light works such as removal of sewerage, disposing of waste material, soil filling, and other lightwork related to construction. In addition, this Excava can also be used for various plantation and forestry purposes [2].

In a wide range of engineering projects, the structural design has always been a very interesting and creative part. Structures should be designed to be able to withstand applied forces (stress constraints) and not surpass such deformations (displacement constraints). Boom is the main component of the 
main excavator, heavier, and very critical, so there is a need for improvement and development [3]. Since excava 50 is a new product, there is a need to improve the design. Therefore, the author is interested in improve the excava 50 design with a focus on analyzing boom components. The results of this analysis are used as standard structures for boom components.

\section{Methodology}

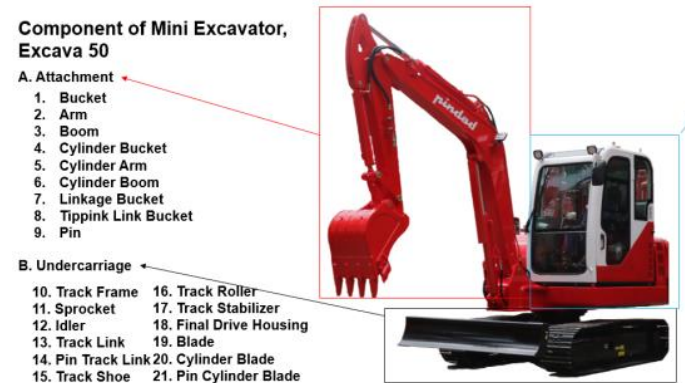

Figure 1. Component of Mini Excavator

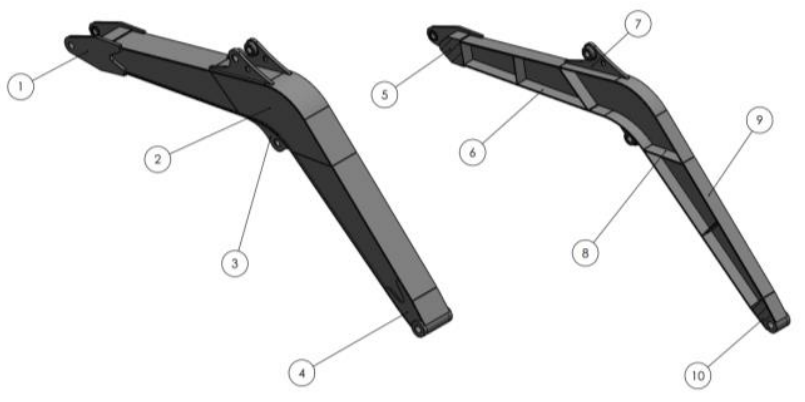

Figure 2. Existing design and section view of boom assy

Figure 2 shows the 3D design model and section view of the boom assy with a description of the parts shown by the figures explained in table 1 . The boom is part of the structure of the excavator that receives the heaviest load when working, therefore a rib plate is needed as a reinforcement for the boom's top and bottom cover plates. The design is based on the manufacturing process, where the plates are connected one by one so that it becomes a boom structure. The material used in this boom is based on the material in the field. That is SM490A with material properties as in the following table.

Table 1. Part list Design Boom Assy

\begin{tabular}{c|l|c}
\hline No & \multicolumn{1}{|c}{ Part Name } & Quantity \\
\hline 1 & Boom to arm connector stiffener & 2 \\
2 & Boom side cover & 6 \\
3 & Cylinder boom mounting & 2 \\
4 & Boom to upper frame connector & 2 \\
& stiffener & \\
5 & Boom reinforcement plate to arm & 1 \\
& connector & 3 \\
7 & Boom bottom cover & 2 \\
8 & Arm cylinder mounting & 4 \\
9 & Boom rib plate & 3 \\
10 & Boom upper cover & 1 \\
\hline
\end{tabular}

Table 2. Material Properties SM490A

\begin{tabular}{c|c}
\hline Properties Material & Value \\
\hline Young's Modulus & $210 \mathrm{GPa}$ \\
Yield Stress & $325 \mathrm{MPa}$ \\
Ultimate Tensile Stress & $490 \mathrm{MPa}$ \\
Poisson Ratio & 0.3 \\
Density & $7,85 \mathrm{~g} / \mathrm{cm}^{3}$ \\
\hline
\end{tabular}

\section{Working Condition}

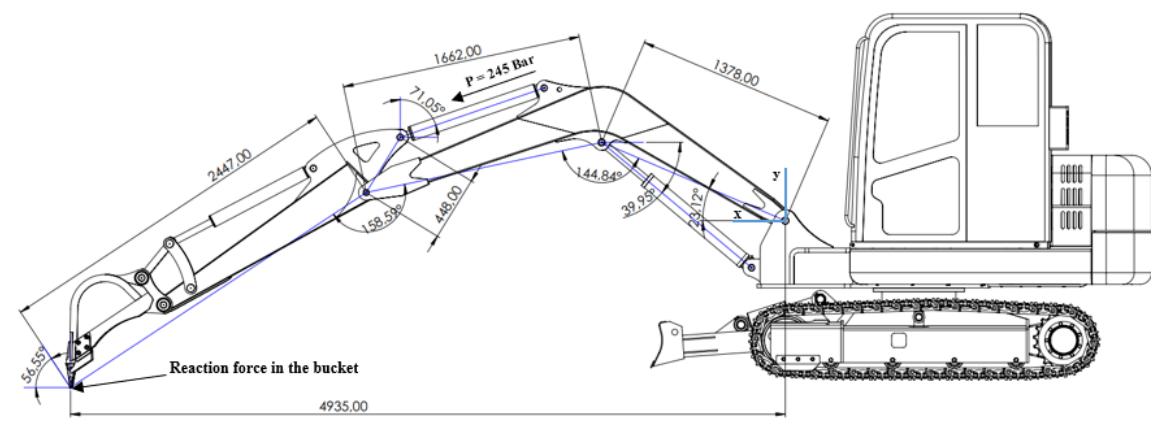

Figure 3. Working Condition of Mini Excavator

In this analysis the structure is assumed to be in a static condition, i.e. the bucket teeth touch a rigid surface so that there is a reaction force that is perpendicular to the bucket. Buckets are positioned 
parallel to the arm. Working pressure on the cylinder arm of 245 bar pushes forward, forcing the arm to rotate counter-clockwise to the xy plane.

Static Analysis using Free Body Diagram (FBD) and Bucket and Arm Static Force

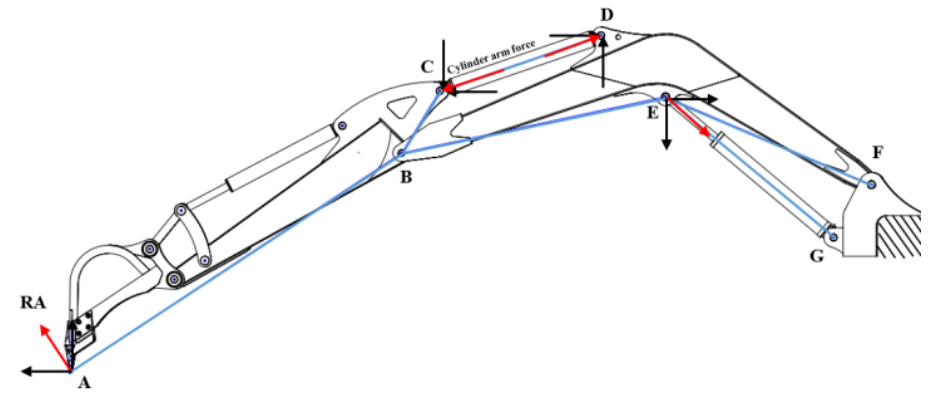

Figure 4. FBD of Mini Excavator

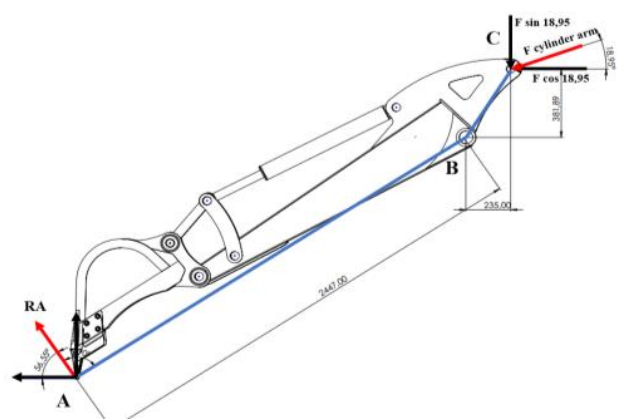

Figure 5. FBD of Bucket and Arm Component

From this figure, there is 1 force that produces 3 reactions. That is the action force on the cylinder $\operatorname{arm}(\mathrm{F})$. When the cylinder arm is active, the arm and bucket will move counter-clockwise. Resulting in reaction forces on bucket teeth (RA), mounting cylinder arms on the boom (RD) and also mounting cylinder boom (RE).

Table 3. Force Contained in Bucket and Arm Component

\begin{tabular}{c|c|c}
\hline \multirow{2}{*}{ Pin } & \multicolumn{2}{|c}{ Force $(\mathrm{kN})$} \\
\cline { 2 - 3 } & $\mathrm{X}$ & $\mathrm{Y}$ \\
\hline RA & -85.91 & 130.04 \\
$\mathrm{RB}$ & 160.40 & 17.56 \\
$\mathrm{RC}$ & -147.41 & -50.61 \\
\hline
\end{tabular}

\section{Boom Static Force}

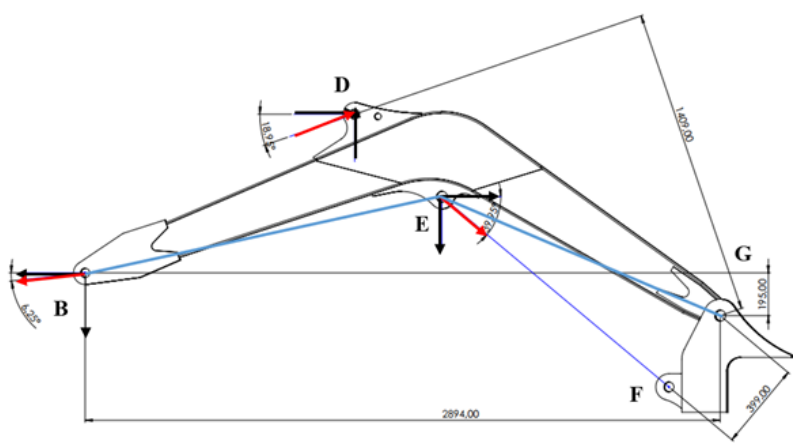

Figure 6. FBD of Boom Component
Table 4. Force Contained in Bucket and Arm Component

\begin{tabular}{c|c|c}
\hline \multirow{2}{*}{ Pin } & \multicolumn{2}{|c}{ Force $(\mathrm{kN})$} \\
\cline { 2 - 3 } & $\mathrm{X}$ & $\mathrm{Y}$ \\
\hline RA & -85.91 & 130.04 \\
$\mathrm{RB}$ & 160.40 & 17.56 \\
$\mathrm{RC}$ & -147.41 & -50.61 \\
\hline
\end{tabular}

Static force in this analysis calculated by considering the summation force must be equal to zero $\left(\sum F=0\right)$ and summation of moment equal to zero $\left(\sum M=0\right)$ for equlibrium condition of the bucket, arm and boom respectively. The negative sign indicates the force acting towards the left on the horizontal component and downward on the vertical force. by considering the direction of force obtained in accordance with the FBD.

\section{Finite Element Analysis}

\section{Design Boom and Applying the Material}

The boom assy mini excavator structure was designed using CAD CATIA V5 Software based on the actual size and for the material that apply in this design accroding the properties material in existing design. 


\section{Define Boundary Condition}

Boundary conditions are the limitations used in a simulation, in this case, modelling loading and setting support. Modelling loading on boom components is carried out statistically. The boom is modelled as a flexible body which is the object that has deformation, while the setting support is modelled as a body or object that has no deformation. Surface loading or support that is applied is cylindrical in shape. Loading is carried out based on the results of a static analysis using the free body diagram that we have done before. The results of loading can be seen in table 4 .

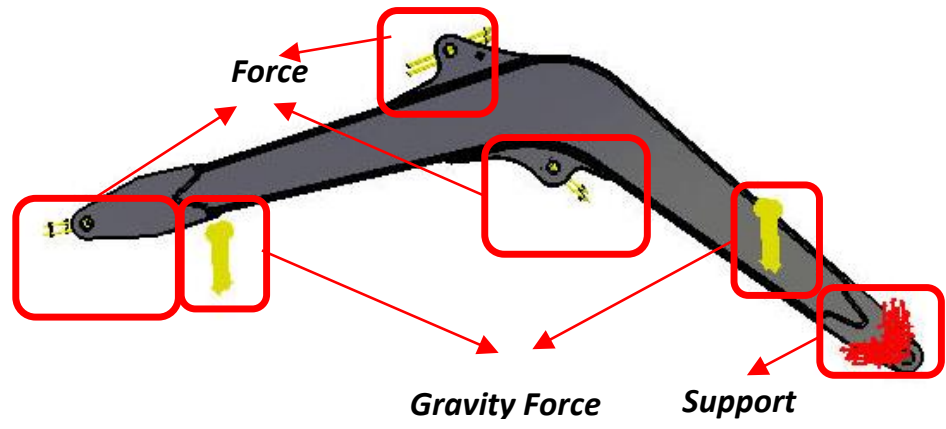

Figure 7. Boundary Condition of Boom Component
Table 5. Setting Support on Boom Component

\begin{tabular}{c|c}
\hline Setting Support & Axis \\
\hline Displacement X & 0 \\
Displacement Y & 0 \\
Displacement Z & 0 \\
Rotation X & 0 \\
Rotation Y & 0 \\
Rotation Z & Free \\
\hline
\end{tabular}

\section{Meshing Validation}

In this validation meshing we will compare which strategies are the most optimal and efficient in this analysis. In this comparison. First, we find the optimal mesh size in reducing element size manually by taking 4 sample nodes at the end of the critical component. after the results obtained stable mesh size. The estimated error rate that we generate is used in the adaptive mesh global strategy. In the global adaptive mesh strategy, we can determine the error rate. The following table shows the comparison results of the two strategies. Table 6 shows that the global adaptive mesh is an efficient and optimal strategy for meshing, which has the same error rate. resulting in shorter computing time and more accurate mesh sizes.

\section{Computational Results}

\section{Estimated Error Rate}

Estimate error rate is the estimation of errors that occur in computing. Below is the equation that is used in making estimation errors in Catia software, where, $\mathrm{E}$ is the global strain energy and e is the estimated precision.

$$
\eta=100 \sqrt{\frac{e / 2}{E+e / 2}}
$$

Table 6. Comparison between reducing element size manually and global adaptive mesh strategy
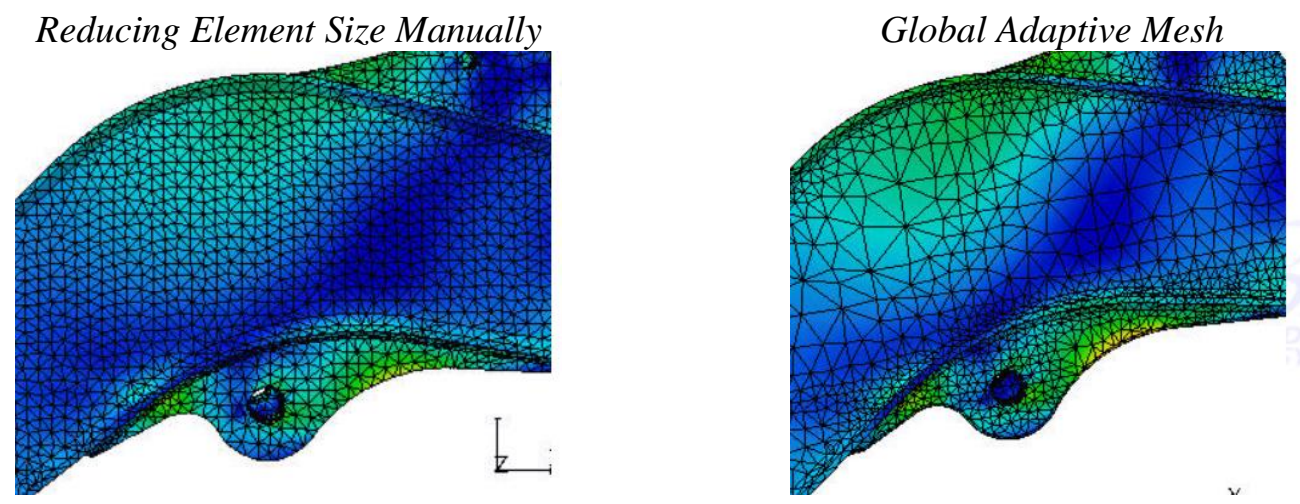


\author{
Mesh Size $15 \mathrm{~mm}$ \\ Von Misses Stress \\ $271 \mathrm{MPa}$ \\ 480 second \\ Error Rate $5.43 \%$
}

\author{
Mesh Size Global Adaptive \\ Von Misses Stress \\ $230 \mathrm{MPa}$ \\ 280 second \\ Error Rate $4.63 \%$
}

\section{Principal and Von Misses Stress Result}

Principal Stress are the maximum values of the normal stresses at the point. In Catia software the equation that used for this computation is:

$$
\sigma_{x . y}=\frac{\sigma_{x}+\sigma_{y}}{2} \pm \sqrt{\left(\frac{\sigma_{x}-\sigma_{y}}{2}\right)^{2}+\tau_{x y}^{2}}
$$

The plus sign indicates for maximum principal stress and minus sign indicates for minimum principal stress as shown in Figure 8 and 9.

Von Mises stress is also called equivalent tensile stress. It's a special measure of stress that serves as an approach to combine all stress components into one value. In the Catia software. Equation used in computing von misses stress is as follows:

$$
\sigma_{v m}=\frac{1}{\sqrt{2}} \cdot \sqrt{\left(\sigma_{x}-\sigma_{y}\right)^{2}+\left(\sigma_{y}-\sigma_{z}\right)^{2}+\left(\sigma_{z}-\sigma_{x}\right)^{2}}
$$

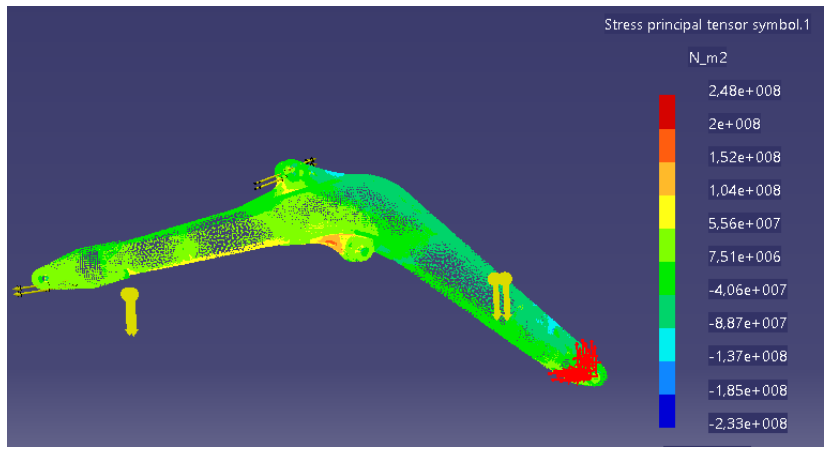

Figure 8. Principal Stress Result

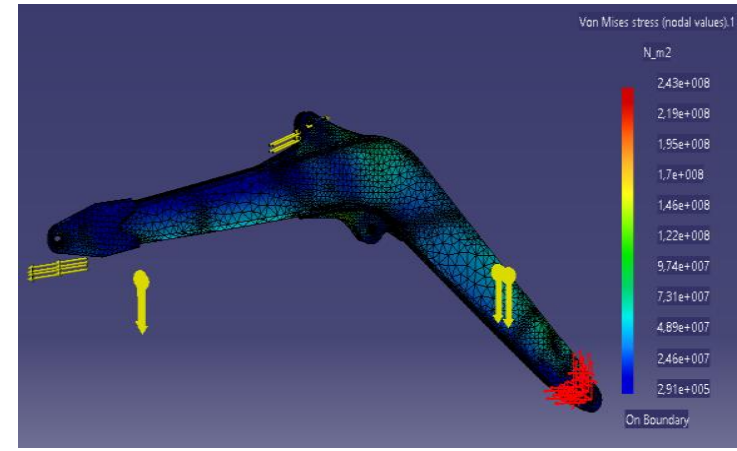

Figure 9. Von Misses Stress Result

\section{Analysis Result}

Based on failure criteria states that Von Misses Stress $\left(\sigma_{v m}\right)$ must be less than the allowable stress $\left(\sigma_{\text {allowable }}\right)$ material by considering the appropriate safety factor. This shows that the design is in a safe condition[4].

Accroding failure criteria, the result is

$$
\begin{aligned}
\text { Von Misses Stress }\left(\sigma_{v m)}\right. & \leq \sigma_{\text {allowable }} \\
\sigma_{\text {allowable }} & =\frac{\text { Yield Stress }}{\text { Safety Factor }}
\end{aligned}
$$

$$
\begin{array}{r}
\text { Von Misses Stress }\left(\sigma_{v m}\right)>\sigma_{\text {allowable }} \\
243 \mathrm{MPa}>108.3 \mathrm{MPa}
\end{array}
$$

From the equation above it proves that the Existing Boom design is not safe because the results of von misses stress $\left(\sigma_{v m}\right)$ and principal stress are still above allowable stress $\left(\sigma_{\text {allowable }}\right)$. Then from these results. We must replace the material and the material we need must have a higher stress yield.

\section{Material Selection}

From the results of the analysis, the material characteristics that we should look for are with higher yield stress because the work of this boom is heavy. From several steel materials, there is one material that is suitable for use in this boom. That is Hardox 400. Hardox 400 is a hard steel that is suitable for long-term use in abrasive environments with high surface pressure. Good bending ability and welding ability. This material is usually applied for container materials, heavy equipment component materials, spare parts for mining machinery, spare parts for factories, concrete mixing and wood 
processing machinery, mining platform structures[5]. Hardox 400 has the following material properties.

Table 7. Material Properties Hardox 400

\begin{tabular}{c|c}
\hline Properties Material & Value \\
\hline Young's Modulus & $210 \mathrm{GPa}$ \\
Yield Stress & $1000 \mathrm{MPa}$ \\
Ultimate Tensile Stress & $1250 \mathrm{MPa}$ \\
Poisson Ratio & 0.29 \\
Density & $7.473 \mathrm{~g} / \mathrm{cm} 3$ \\
\hline
\end{tabular}

Based on Failure Criteria, the result will be:

$$
\begin{gathered}
\text { Von Misses Stress }\left(\sigma_{v m}\right)<\sigma_{\text {allowable }} \\
243 \mathrm{MPa}<333.3 \mathrm{MPa}
\end{gathered}
$$

The results of the equations above indicate that the design is safe to use. However, one aspect if we replace the material in the existing design with new material. Then the product costs will increase because of the price of new material that is Hardox 400 is more expensive than SM490A. By considering these aspects, we will carry out design improvement. The aim is to optimize the use of material so that product costs are reduced.

\section{Design Improvement}

Design Improvement is the process of improve the design with the aim is to optimize the use of material so that product costs are reduced. In the design improvement we use optimization methods.

\begin{tabular}{|c|c|c|c|c|c|}
\hline \multirow{13}{*}{$\begin{array}{l}\text { Figure 10. Comparison Between Existing Design } \\
\text { and Improvement Design }\end{array}$} & \multicolumn{5}{|c|}{ Table 8. Table Modification Thickness of Boom } \\
\hline & \multirow[b]{2}{*}{ No } & \multirow[b]{2}{*}{ Part Name } & \multirow[b]{2}{*}{ Qty } & \multicolumn{2}{|c|}{ Modification Thickness } \\
\hline & & & & $\begin{array}{l}\text { Existing } \\
\text { Design }\end{array}$ & $\begin{array}{c}\text { Improvement } \\
\text { Design }\end{array}$ \\
\hline & 1 & $\begin{array}{l}\text { Boom to arm } \\
\text { connector stiffener }\end{array}$ & 2 & 20 & 16 \\
\hline & 2 & Boom side cover & 6 & 8 & 6 \\
\hline & 3 & $\begin{array}{l}\text { Cylinder } \quad \text { boom } \\
\text { mounting }\end{array}$ & 2 & 18 & 16 \\
\hline & 4 & $\begin{array}{l}\text { Boom to upper frame } \\
\text { connector stiffener }\end{array}$ & 2 & 10 & 10 \\
\hline & 5 & $\begin{array}{l}\text { Boom reinforcement } \\
\text { to arm connector }\end{array}$ & 1 & - & - \\
\hline & 6 & Boom bottom cover & 3 & 8 & 6 \\
\hline & 7 & $\begin{array}{l}\text { Arm } \\
\text { mounting }\end{array}$ & 2 & 18 & 16 \\
\hline & 8 & Boom rib plate & 4 & 6 & 6 \\
\hline & 9 & Boom upper cover & 3 & 8 & 6 \\
\hline & 10 & $\begin{array}{l}\text { Boom to upper frame } \\
\text { connector }\end{array}$ & 1 & 26 & 26 \\
\hline
\end{tabular}
That is Sizing optimization and shape optimization.

\section{Finite Element Analysis Result from Design Improvement}

\section{Principal Stress and Von Misses Stress}

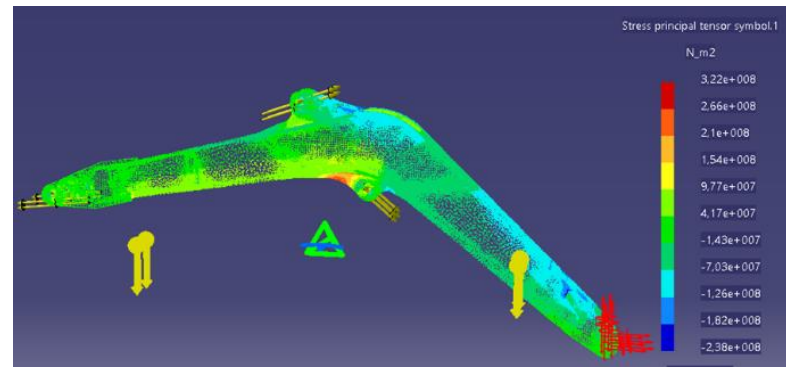

Figure 11. Principal Stress Result of Improvement Design

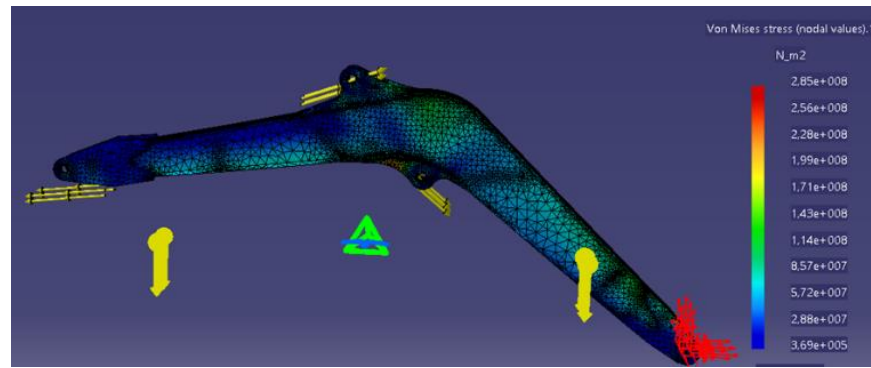

Figure 12. Von Misses Stress Result of Improvement Design 


\section{Analysis Result from Design Improvement}

From the analysis using the finite element method in design improvement and by considering the safety factor of 3 with the aim to minimize the potential failure parts. Then the results of design optimization can be concluded with the equation [5]:

$$
\sigma \_\mathrm{M} /\left(\sigma_{-} \mathrm{W}\right)=\text { Factor of Safety }
$$

Data

$$
\begin{array}{ll}
: \text { Yield Strength Material Hardox } 400 & =1000 \mathrm{MPa} \\
: \text { Max Von Misses Stress } & =285 \mathrm{MPa} \\
: \text { Max Principal Stress } & =322 \mathrm{MPa}
\end{array}
$$

Based on Von Misses Stress. The results are as follows:

Based on Principal Stress. The result is as follows:

$$
\sigma \_\mathrm{M} /\left(\sigma_{-} \mathrm{W}\right)=(1000 \mathrm{MPa}) /(285 \mathrm{MPa})=3.50
$$

$$
\sigma \_\mathrm{M} /\left(\sigma \_\mathrm{W}\right)=(1000 \mathrm{MPa}) /(322 \mathrm{MPa})=3.10
$$

From the results of the two equations above. By maintaining the safety factor 3 , the two results above exceed 3. This proves the design has been declared safe for use.

\section{Fatigue Life Calculation}

The purpose for cal is to predict how long the boom component can be used. Fatigue life calculation data is taken from the analysis of design improvement results with the following data:

- Stress Maximum $\left(\sigma_{\max }\right)$ is the stress that occurs in the boom mini excavator by being given a workload based on the static analysis that we have determined (See figure 12).

- Stress Minimum $\left(\sigma_{\min }\right)$ is the stress that occurs on boom mini excavator when there is no force on the workload (only gravitational force).

- Data Ultimate Tensile Stress of Material Hardox 400 is $1250 \mathrm{MPa}$

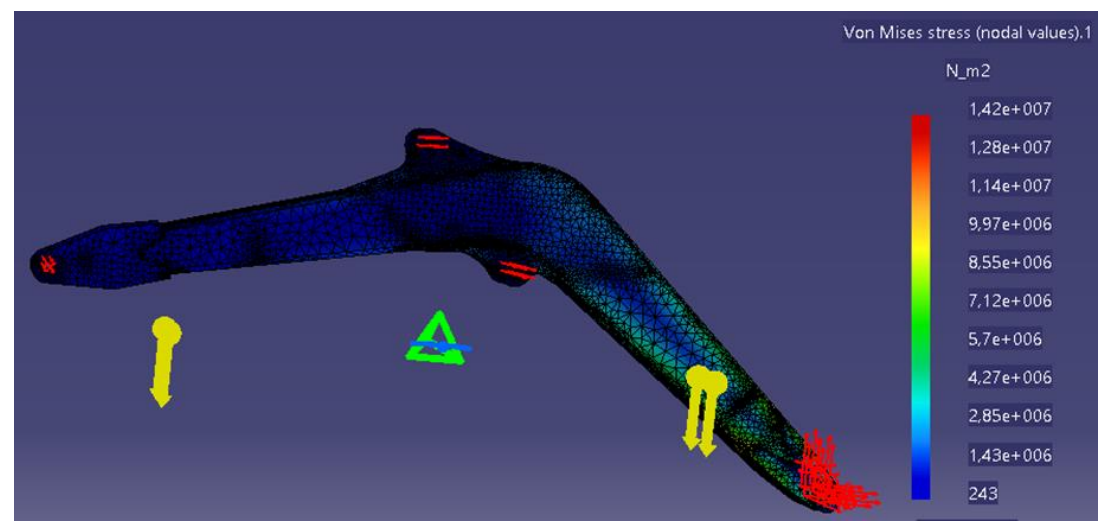

Figure 13. Minimum Stress on Improvement Design

In this fatigue life calculation, we use Goodman's theory. The following is a calculation in determining fatigue life calculation

- Mean Stress $\left(\sigma_{m}\right)$

- Alternating Stress $\left(\sigma_{a}\right)$

$$
\sigma_{m}=\frac{\sigma_{\max } \sigma_{\min }}{2}=\frac{285 \mathrm{MPa}+14.2 \mathrm{MPa}}{2}=149.85 \mathrm{MPa}
$$

- Slope $(m)$

$$
\sigma_{a}=\frac{\sigma_{\max }-\sigma_{\min }}{2}=\frac{285 \mathrm{MPa}-14.2 \mathrm{MPa}}{2}=135.15 \mathrm{MPa}
$$

$$
m=\frac{\sigma_{a}}{\sigma_{m}}=\frac{135.15 \mathrm{MPa}}{149.85 \mathrm{MPa}}=0.90
$$

- Coordinate (y)

$$
\begin{aligned}
y & =\sigma_{e}-m . \sigma_{m}=\frac{\text { Ultimate Tensile Stree }}{2}-m . \sigma_{m} \\
& =625 \mathrm{MPa}-0.90 .149 .85 \mathrm{MPa}=490.135 \mathrm{MPa}
\end{aligned}
$$

- Margin of Safety (M.S) 
$M . S=\frac{y}{\sigma_{a}}=\frac{483.74 \mathrm{MPa}}{142.68 \mathrm{MPa}}=3.626$

- Fatigue Life

Fatigue Life $=$ Total life of material in cycles $\cdot\left(1-\left(\frac{1}{\text { M.S }}\right)\right)=7242140$ cycles

\section{Result and Discusion}

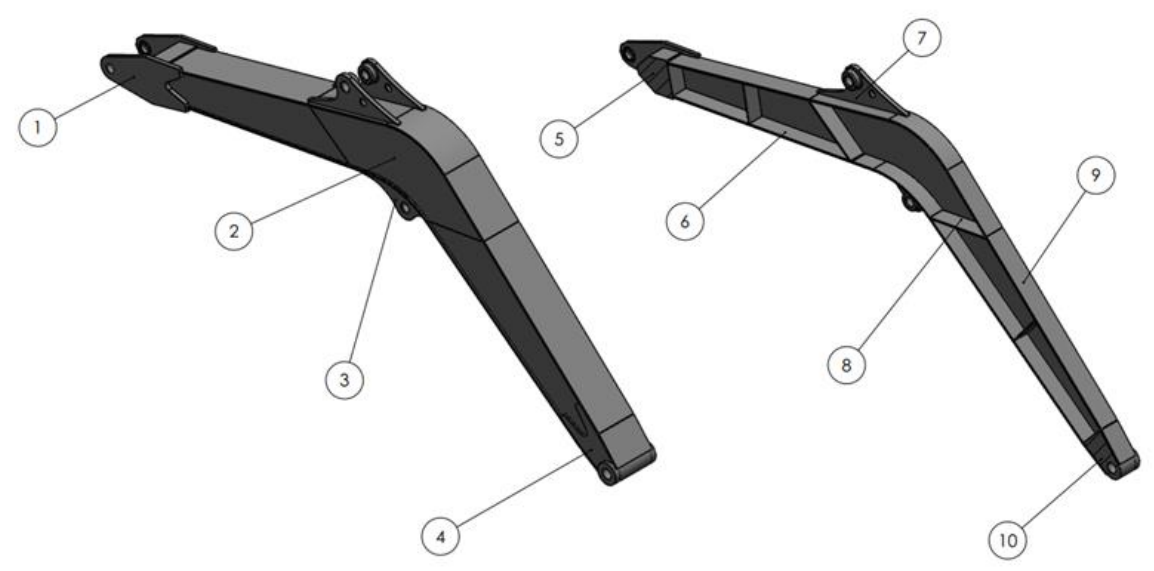

Figure 14. Parts of the boom

Table 9. Comparison of thickness and weight of the material

\begin{tabular}{|c|c|c|c|c|c|c|}
\hline \multirow[b]{2}{*}{$\begin{array}{l}\text { Part } \\
\text { No. }\end{array}$} & \multirow[b]{2}{*}{ Part Name } & \multirow[b]{2}{*}{ Qty } & \multicolumn{2}{|c|}{ Modification } & \multicolumn{2}{|c|}{ Total Weight } \\
\hline & & & $\begin{array}{l}\text { Existing } \\
\text { Design }\end{array}$ & $\begin{array}{c}\text { Improvement } \\
\text { Design }\end{array}$ & $\begin{array}{l}\text { Existing } \\
\text { Design }\end{array}$ & $\begin{array}{c}\text { Improvement } \\
\text { Design }\end{array}$ \\
\hline 1 & Boom to arm connector stiffener & 2 & 20 & 16 & 23.260 & 17.756 \\
\hline 2 & Boom side cover & 6 & 8 & 6 & 74.442 & 52.900 \\
\hline 3 & Cylinder boom mounting & 2 & 18 & 16 & 12.302 & 7.630 \\
\hline 4 & $\begin{array}{l}\text { Boom to upper frame connector } \\
\text { stiffener }\end{array}$ & 2 & 10 & 10 & 4.522 & 4.522 \\
\hline 5 & $\begin{array}{l}\text { Boom reinforcement plate to arm } \\
\text { connector }\end{array}$ & 1 & - & - & 38.005 & 38.005 \\
\hline 6 & Boom bottom cover & 3 & 8 & 6 & 36.690 & 24.760 \\
\hline 7 & Arm cylinder mounting & 2 & 18 & 16 & 14.062 & 11.368 \\
\hline 8 & Boom rib plate & 4 & 6 & 6 & 7.155 & 3.594 \\
\hline 9 & Boom upper cover & 3 & 8 & 6 & 39.151 & 27.230 \\
\hline 10 & Boom to upper frame connector & 1 & 26 & 26 & 38.400 & 38.400 \\
\hline \multicolumn{5}{|c|}{ Total Weight } & 287.989 & 226.165 \\
\hline
\end{tabular}

Table 10. Comparison Total Weight of Boom

\begin{tabular}{c|c|c|c|c}
\hline $\begin{array}{c}\text { Name of } \\
\text { Part }\end{array}$ & $\begin{array}{c}\text { Total Weight } \\
\text { Existing Design }(\mathrm{Kg})\end{array}$ & $\begin{array}{c}\text { Total Weight } \\
\text { Improvement Design }(\mathrm{Kg})\end{array}$ & $\begin{array}{c}\text { Reduction in } \\
\text { Weight }(\mathrm{Kg})\end{array}$ & $\begin{array}{c}\text { Percentage } \\
\text { Reduction in Weight }\end{array}$ \\
\hline Boom & 287.989 & 226.165 & 61.824 & 21.46 \\
\hline
\end{tabular}

Table 11. Comparison Von Misses Stress of Boom

Existing Design

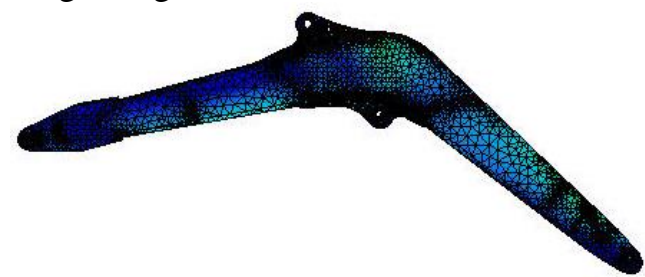

Von Misses Stress
Improvement Design

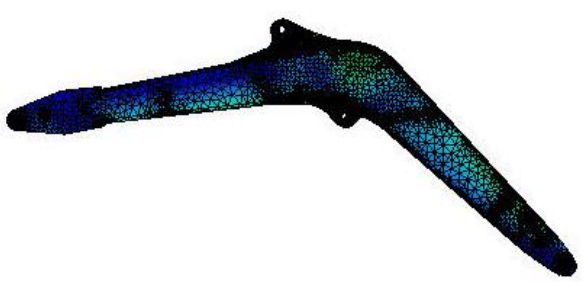

Von Misses Stress

\begin{tabular}{c|c} 
Maximum & Minimum \\
$285 \mathrm{MPa}$ & $0.369 \mathrm{MPa}$
\end{tabular}


Table 12. Increased of Von Misses Stress

\begin{tabular}{c|c|c|c|c}
\hline \multirow{2}{*}{ Name of Part } & \multicolumn{2}{|c|}{ Maximum Von Mises Stresses Produced (MPA) } & $\begin{array}{c}\text { Increase in } \\
\text { (MPa) }\end{array}$ & $\begin{array}{c}\text { Percentage } \\
\text { Increase }\end{array}$ \\
\cline { 2 - 3 } Boom & Existing Design & Improvement Design & $42 \mathrm{MPa}$ & 14.7 \\
\hline
\end{tabular}

Table 13. Comparison of Principal Stress of Boom

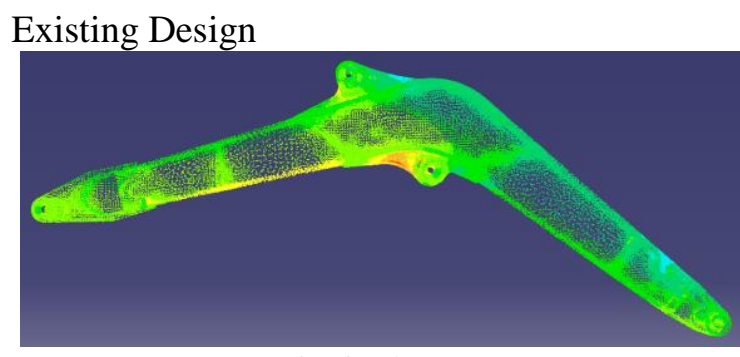

Principal Stress

Maximum

$248 \mathrm{MPa}$
Improvement Design

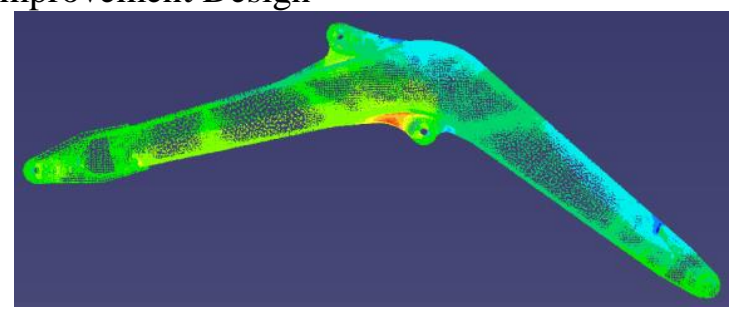

Principal Stress

\begin{tabular}{c|c} 
Maximum & Minimum \\
$322 \mathrm{MPa}$ & $-238 \mathrm{MPa}$
\end{tabular}

Table 14. Increased of Principal Stress

\begin{tabular}{c|c|c|c|c}
\hline \multirow{2}{*}{ Name of Part } & \multicolumn{2}{|c|}{ Maximum Principal Stresses Produced (MPa) } & $\begin{array}{c}\text { Reduction } \\
\text { in (MPa) }\end{array}$ & $\begin{array}{c}\text { Percentage } \\
\text { Reduction }\end{array}$ \\
\cline { 2 - 3 } Boom & Existing Design & Improvement Design & $74 \mathrm{MPa}$ & 22.98 \\
\hline
\end{tabular}

\section{Fatigue Life Result}

Mean stress is the average stress of maximum stress and minimum stress, while alternating stress or also known as stress amplitude is the difference between peak stress and average stress. Mean stress $\left(\sigma_{\mathrm{m}}\right)$ is $149.85 \mathrm{MPa}$ and alternating stress $\left(\sigma_{\mathrm{a}}\right)$ is $135.15 \mathrm{MPa}$. The graph as shown in Figure 15 and 16. After getting mean and alternating stress, then calculate fatigue life by using Goodman's theory.

- Slope $(\mathrm{m})$

$$
\mathrm{m}=\frac{\sigma_{\mathrm{a}}}{\sigma_{\mathrm{m}}}=\frac{135.15 \mathrm{MPa}}{149.85 \mathrm{MPa}}=0.90
$$

- Coordinate $(\mathrm{y})$

$$
\begin{aligned}
\mathrm{y} & =\sigma_{\mathrm{e}}-\mathrm{m} \cdot \sigma_{\mathrm{m}}=\frac{\text { Ultimate Tensile Stree }}{2}-\mathrm{m} \cdot \sigma_{\mathrm{m}} \\
& =625 \mathrm{MPa}-0.90 .149 .85 \mathrm{MPa}=490.135 \mathrm{MPa}
\end{aligned}
$$

- Margin of Safety (M.S)

$$
\text { M. } S=\frac{y}{\sigma_{a}}=\frac{483.74 \mathrm{MPa}}{142.68 \mathrm{MPa}}=3.626
$$

- Fatigue Life

Fatigue Life $=$ Total life of material in cycles $\cdot\left(1-\left(\frac{1}{\text { M.S }}\right)\right)=7242140$ cycles

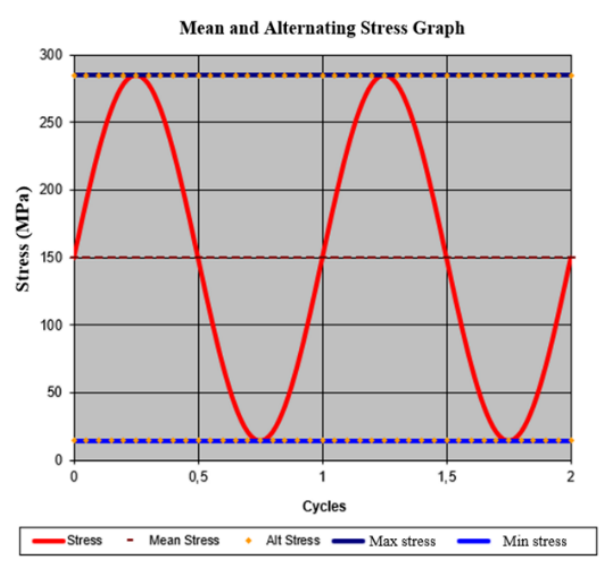

Figure 15. Mean and Alternating Stress Graph

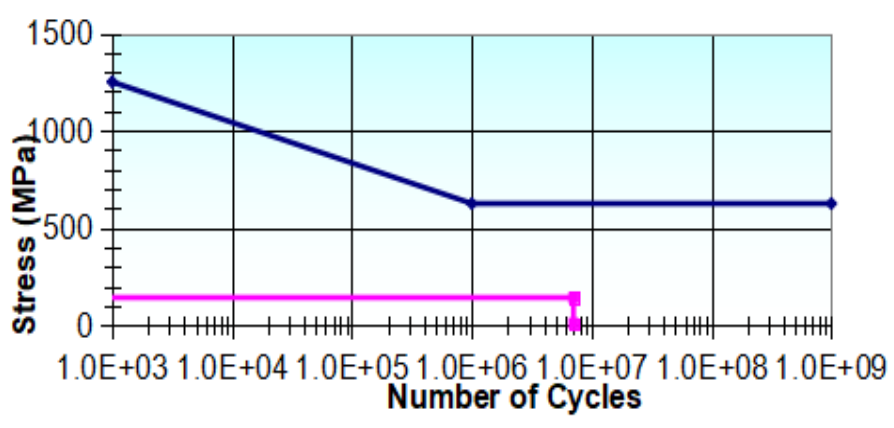

Figure 16. SN-Diagram 
- Life Time

To prove that the boom mini excavator can be used for a long time, life time calculation is needed. In determining life time. We must know the working cycle of the mini excavator in light work (digging). The following are working conditions of mini excavators based on field observations

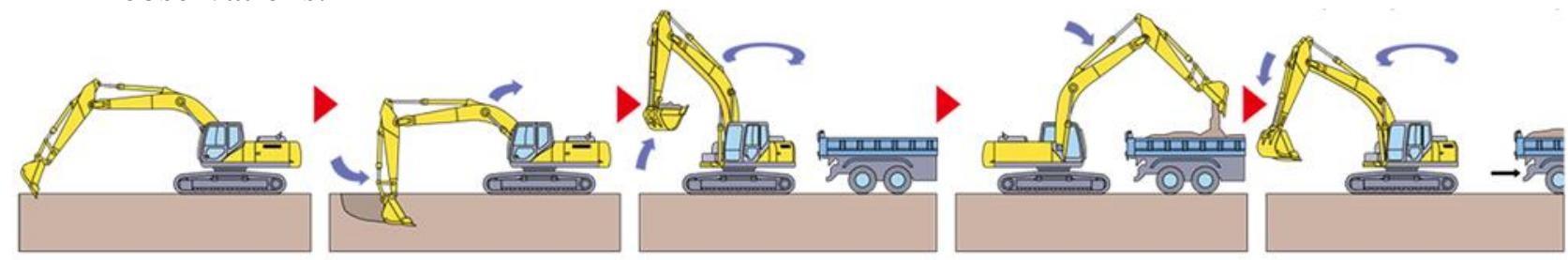

Figure 17. Working cycles of Mini Excavator

Based on observations above, that the total working cycle of the mini excavator is 40 seconds / cycle. So, for 1 year will be 194400 cycles/year.

$$
\text { Life Time }=\frac{\text { Fatigue Life Cycles }}{\text { Cycles of use in 1 year }}=\frac{7242140 \text { cycles }}{194400 \text { cycles } / \text { year }}=37.25 \text { year }
$$

From the above calculation, the use of the boom mini excavator can be used for 37 years. This proves that based on life time calculation,. mini boom excavators can be used for a long period of time.

\section{Conclusion}

Existing Design using SM490A Material when it is given load according to static analysis using Free Body Diagrams. The result is the design is not safe. By considering these results. The material in the existing design is replaced with Hardox 400 material because the material has a high-stress yield, with the same load given by considering the same safety factor of 3 , the result is that the design is safe to apply. However, product costs will increase. Because Hardox 400 material is more expensive than SM490A material.

From these 2 optimization methods, the weight of the boom component has decreased by $21.46 \%$ or $61,824 \mathrm{~kg}$. This will reduce the use of materials so that product costs come down. On improvement design using optimization method. We calculate fatigue life by using Goodman's theory, the result is that the boom can last for 7242140 cycles, these results indicate that the use of a boom is declared to be infinite and for life time is 37 year. so that the boom can be used for a long period of time.

\section{References}

[1] Nur Mahasih Hapsari, "Infrastruktur Jalan di Pedesaan,” Kompasiana, 2019.

[2] PT. Pindad (Persero), "PINDAD LAUNCHING EXCAVA 50 , VARIAN MINI EXCAVATOR,” pp. 1-5, 2020.

[3] N. S. Patil and P. V. M, "FEA Analysis and Optimization of Boom of Excavator," no. June, pp. 625-632, 2017.

[4] T. R. Chandruptla and Ashok D. Belegundu, "Introduction to Finite Element Engineering.pdf." .

[5] C.F.Zorowski, "Factor of Safety," pp. 145-168. 